CHAPTER 1

\title{
Contemporary Indigenous Research within Sámi and Global Indigenous Studies Contexts
}

\author{
Pirjo Kristiina Virtanen, Torjer Olsen and Pigga Keskitalo
}

\begin{abstract}
This chapter addresses the genealogy of Indigenous studies, and how it is conceptualized and practised in the Sámi context. It discusses the inclusion of Indigenous knowledges and Indigenous ways of doing research in academia, as well as the role of Indigenous research methodologies in this effort. We link our chapter to larger academic Indigenous discussions on the concepts of 'knowledge', 'decolonization', 'research' and 'indigenization'. At the theoretical and practical levels these processes and initiatives have enabled researchers to shed light on Indigenous views on the past, the present, and the future, first of all in Indigenous societies, but also in academia. This chapter also addresses the challenges of moving between local and global levels. Indigenous research contexts are diverse and dynamic, and the key to creating dialogues, bridges, and collaboration, lies in this very diversity, complexity, and multivocality of Indigenous societies.
\end{abstract}

\section{Keywords}

Sámi studies - Indigenous studies - Indigenization - decolonization - Indigenous research methodologies - Indigenous paradigm

Even though many scholars would argue that Indigenous studies belongs within different kinds of cultural or ethnic studies, today it is a field of its own. It has its own scientific journals, academic events, as well as specially targeted funding mechanisms and strategic plans within education institutions. This chapter aims to discuss the inclusion of Indigenous knowledges and Indigenous ways of doing research in academia, as well as the role of Indigenous research methodologies in this effort. It sheds light first on the genealogy of Indigenous studies, the Sámi context in particular.

(C) PIRJO KRISTIINA VIRTANEN, TORJER OLSEN AND PIGGA KESKITALO, 2021 
We link our chapter to larger academic Indigenous discussions on the concepts of 'knowledge', 'decolonization', 'research' and 'indigenization'. These concepts offer common points in Indigenous studies, and have been studied in diverse Indigenous locations. In addition to the research work carried out previously in the field, the authors' experiences of teaching and researching in Sámi Research and global Indigenous Studies and related programmes provide an important mirroring point. We present the programmes addressed in crossborder contexts, as well as the ideas of students in our study programmes. These views were collected in the course evaluations, which revealed the hopes and ideas of students' roles concerning their studies. The evaluations showed that students aimed to bring forth transformations in communities and societies, and indicated that researchers had a strong sense of individual responsibility in these projects. Pirjo Kristiina Virtanen works as an Associate Professor in Indigenous Studies at the University of Helsinki. Torjer Olsen works as a Professor in the Indigenous Studies Centre for Sámi Studies and is the Head of Department. Pigga Keskitalo works as a part time Associate Professor at the Sámi University of Applied Sciences in a Sámi teacher education programme and at the University of Lapland as a researcher.

Indigenous perspectives are diverse and dynamic, as they draw from the various aspects of Indigenous societies' practices, languages, histories, landscapes, and ways of living. The same applies to Sámi studies and Sámi society. Therefore, we aim here to go beyond clear-cut distinctions between Indigenous and non-Indigenous perspectives and avoid homogeneous and universal categorizations. We highlight the fact that Indigenous research methodologies do not only allow raising attention to diverse onto-epistemologies, but also more horizontal, relational, and accountable encounters in research (see Porsanger 2004; Weber-Pillwax 1999; Wilson 2008). Yet, such methodological efforts require critical reflections concerning the meaning of knowledge building and its methods in each local Indigenous context.

In what follows, the history of global Indigenous and Sámi studies is presented, and their approaches, overarching topics, concepts, and places in academia are discussed. As will be seen, the conceptualization of Indigenous studies as a discipline, its objectives, and thus how it is practised, is also related to Indigenous views on the past, the present, and the future.

\section{The Sámi in the World of Research}

Sámi research as a field of study is understood as research with Sámi contents from a Sámi standpoint and with the aim of producing knowledge about Sámi people using their own premises and Sámi language terminology. It can cover 
among other things, Sámi history, society, language, material and non-material culture, as well as environmental issues (Lehtola \& Länsman 2012; Sergejeva 2002; Seurujärvi-Kari 2014a; Seurujärvi-Kari et al. 2011).

Sámi research itself has a long history (see Chapter 2 in this volume). Sámi intellectuals, since the 17th century, gave a deep account of the genealogy of Sámi research up until the 1970s. For centuries, missionaries and explorers actively travelled and explored the wide Sápmi (Sámi areas) (see e.g. Pulkkinen 2005). For religious purposes, missionary activities created the first Sámi writings as early as 1619 (Capdeville 2014). From the 17th century on, church schools were organized that gathered in Sámi children (Hirvonen 2004). The occasional use of the Sámi language was one means to introduce Christianity for the Sámi people (Minde 2003). This is a period of different unifying ideologies, such as the Enlightenment, highlighting the ideas of human rationality, and excluding many people who were considered culturally different. From the 185 os onwards, early institutionalized education was provided in different forms of assimilation processes in the different nation states where Sámi people lived. Gradually, the Sámi adapted to the customs, language, and attitudes of the mainstream culture (see Pauls 2019), and their children began to attend residential schools (Rasmus 2014).

The Sámi have been among the most researched Indigenous peoples in the world, and like many other Indigenous peoples around the globe they have long been the object of "Western" scholarship (Lehtola \& Länsman 2012). One of the early research traditions related to the Sámi was Lappological research conducted by outside researchers from the 18th and 19th centuries onwards. These researchers represented different fields of science, from linguistics to philanthropy, and their research was conducted in Finnish, Norwegian, Swedish, German, Italian, and French, among other languages. Lappological traditions have been largely tainted by racist and stereotype ideologies until the middle of the twentieth century (e.g. Isaksson 2001; Seurujärvi-Kari 2014a). Racist attitudes were not the only ones, however, as Lappologist researchers were diverse and represented a variety of different approaches (Lehtola 2017).

Contrary to this tradition, Sámi scholar Alf Isak Keskitalo, among other forerunners, criticized the ways that Sámi were situated and represented in research. He argued in 1974 that the Sámi were only considered research objects and 'others', and called for a change in this hierarchical research design (Keskitalo 1974/1976, see also Chapter 2 in this volume). A. I. Keskitalo's views have been recognized as an inevitable turning point in the rise of new Sámi research and have justified Sámi's own research institutions. His views also marked a shift from the former Lappological approach to a new mode of Sámi research in which the voice and research needs of the Sámi themselves were central (Stordahl 2008; Thuen 1995). This occurred as a continuum to the 
Sámi movement, active since the early 19oos. The movement established a Sámi cultural and political awakening and later, other transformations, such as the establishment of the Davviriikkaid Sámi Instituhtta, Nordic Sámi Institute (NSI), in Guovdageaidnu (Kautokeino), Norway, in 1973. In addition, in the late 1970s, the Sámi movement was active because of the Alta dam conflict, which united Sámi people and gave a voice to Sámi rights.

The notion at the time that the Sámi themselves should decide how research was conducted, was part of the rise of the Indigenous decolonialism that emerged in the 196os, which has been getting stronger ever since. In all the countries where the Sámi people live, Sámi studies from Sámi standpoints have been conducted in a variety of forms during their history. Sámi language studies began in Tromsø in the 1970s, at the Universities of Helsinki, Oulu, and Lapland in Finland since the 1980s (Lehtola 2014; Rantala 2014; Seurujärvi-Kari 2014b), in Guovdageaidnu Sámi allaskuvla (Sámi University of Applied Sciences) since 1989, and in Sweden since 2000 (Centre for Sámi Research 2020).

International Connections in the Emergence of Indigenous Studies as a Discipline

Local and global politics have contributed to many transformations in science. Developments in the Indigenous field were connected to worldwide processes after WW2 inputting efforts on human rights perspectives. This was also a time when many former colonial countries became independent, and coincided with an increased political awareness of the struggles that Indigenous peoples had experienced for centuries (see e.g. Hill 2010). Among others, since the 196os, Native American scholar, Vine Deloria Jr. (1970a, 197ob), wrote about the invisible history of the Indigenous peoples research in the U.S. Furthermore, in 1975, the first Indigenous Peoples World Council (WCIP) was held in Port Alberni in Canada, where common Indigenous issues were addressed.

Indigenous academic discussions were also strongly related to postcolonial thinking, which emerged in the 196os. Or to put it in another way, postcolonial thinkers have acted in parallel with several Indigenous scholars worldwide since the end of the 196os. Among them are Frantz Fanon (1965, 1965/1967) and Edward Saïd (1979), who founded and illuminated the field of postcolonial studies, representing alternative perspectives on gaps in cultural and political understanding. The roots of postcolonial critique go far back. Among others, in the 19th century, works like Joseph-Ernest Renan's La Réforme intellectuelle et morale (1871) presented colonialism as "the extension of civilisation", which ideologically justified the self-ascribed racial and cultural superiority of the 
"Western" world over the "non-Western" world (see Saïd 2000). "Western" is a contested term, like "Euro-American", but here we use it to refer to the influences of certain political, cultural, and economic features and influences that largely originate among European thinkers, and later also to the colonial powers established in the United States and Australasia. "Western" and "the West" are not concise analytical concepts. They are often used to describe and articulate a particular perspective. In the context of Indigenous research, the concepts are most often used as an opposition to what is Indigenous. Later, the work of Amar Acheraiou (2008), Homi K. Bhabha (1994), Gayatri Spivak (1990), Raman Siva Kumar (1999), and Dipesh Chakrabarty (2000/2007), among others, had a crucial impact on the development of postcolonial theory and studies.

Local Indigenous intellectual discussions also elaborated in relation to, and as part of, shared global dialogues, and Sámi research also contributed to the foundation of Indigenous studies globally. Furthermore, Indigenous scholars were also active in student movements and this also gave a voice to Indigenous students. As one of the results of these diverse global changes, Māori scholar Linda Tuhiwai Smith (1999/2012) wrote Decolonizing Methodologies, which became a monument in global discourse on Indigenous research with the recognition that "research is not an innocent or distant academic exercise but an activity that has something at stake and that occurs in a set of political and social conditions" (Smith L. T. 1999/2012, 5; also Löf \& Stinnerbom 2016, 140). It has paved the way for Indigenous scholars who have felt the need to present their communities' points of view and histories from the inside, and to carry out research differently from the dominant "Western" mode. In Aotearoa New Zealand, the Kaupapa Māori movement by Māori scholars has become a foundation and a framework both for research, education and other related practices. In research it means research done in the Māori way. In practice, this research is done by Māori, for Māori, with Māori, and from a Māori perspective (Smith L. T. 1999/2012).

The developments in different Indigenous contexts, including the Sámi, draw from quite independent ideas, even if the processes of calling for a new type of research and inclusion of Indigenous peoples were occurring at the same time. In addition to the Kaupapa Māori movement (Smith G. H. 1997, 2003; Bishop 1996) in Aotearoa, Indigenous studies also relates to the many peoples of the Americas (Deloria 1970a, 197ob, 1998; Kovach 2009; Wilson 2001, 2008), to Sápmi, Sámi homeland (Gaski 2004; Hirvonen 2008; Kuokkanen 2000, 2007a; Lehtola \& Länsman 2012; Porsanger 2004; Seurujärvi-Kari 2000), to Australia (e.g. Nakata 2007), to Asia (Mao et al. 2012), Asia Pacific (Dirlik 2006), and to Africa (e.g. Chilisa 2012). The terms vary, but the ideas have a similar resonance across local contexts within a wide geographical area. 
This coming up with similar ideas also empowered Indigenous scholars, and led to the inauguration of Indigenous Studies programmes in a number of universities around the world. In several parts of the Indigenous world, from Aotearoa New Zealand, Australia, Sápmi, and the Americas, Indigenous research, Indigenous theories and research methodologies have been developed and come into being as an important part of creating and strengthening Indigenous knowledge both globally in academia. For a long time, Indigenous knowledge-making practices in diverse Indigenous contexts have inspired and guided educators.

Bringing Indigenous knowledge into academia as valid knowledge has been one of the uniting aims in Indigenizing and decolonizing academia (Battiste 2000, 2013; Mihesuah \& Wilson 2004; Wilson 2013). In several Indigenous contexts, despite the local differences in the content, knowledge is considered to be relational and place-based, built in relations that include other-than-humans and the land (e.g. Wilson 2001; Guttorm 2011; Helander 2016; Valkonen \& Valkonen 2019). These relations are all connected with protecting the land and to many other social and economic issues. Indigenous knowledge draws from observations and experiences of generations, transmitted through chants, art, and intergenerational oracity (Chilisa 2012). Through the presence of Indigenous studies, Indigenous knowledge is finding a more legitimate space in academia and elsewhere, such as in policy making.

Indigenization and decolonization have become defining parts of Indigenous studies. Decolonization deals with different forms of knowing that originate from sources other than Eurocentric academic traditions. According to Walter Mignolo (2011), a decolonial view of the world looks critically at the geopolitics of knowledge and aims to go beyond Eurocentrism and Euro-American emphases. It allows different views of the present, the colonial past, and the pre-colonial past to emerge or become visible (Hutchings \& LeeMorgan 2016, 3-5; Smith L. T. 1999/2012, 23-24). Space is made for these connections and sources of knowledge and light are shone on them.

Decoloniality differs from postcolonialism. The latter presupposes something that has ended, whereas from the perspective of decolonization, colonization and imperialism are seen as processes that are still ongoing. Decolonial studies started from the "inside", with one's own language, concepts, theories, and methods. For Indigenous peoples, a key issue in decolonization is to move beyond the suppression and denial of Indigenous languages, histories, and 
knowledge bases, and instead to work with Indigenous concepts, methods and/or institutions, depending on the context. Decolonization is about taking different epistemologies and knowledge-production seriously.

In the context of Indigenous studies, decolonization allows a critical exploration of how existing research has been conducted through the impact of more or less colonizing methods and concepts. It also means carrying out research which does not replicate the damaging impact of colonization (Pihama 2016, 103). As research has shown, minds like territories can be colonized. However, decolonization debates have been criticized for creating new dualisms, and for essentializing and simplifying cultures.

In Indigenous studies, decolonization is also connected to the move towards Indigenization, an approach with a number of starting points. According to Martin Nakata (2006, 269), the process of Indigenization in Australia has been important on several levels. Indigenization of research and academic work has meant making a recognizably Indigenous space within universities, a space that works to culturally affirm Indigenous people and practices. Indigenous scholars shed light on a new perspective and aim at deconstructing Eurocentric hierarchies and dichotomies and highlighting holistic thinking (Chilisa 2012, 40-41; Kuokkanen 2000).

From these settings have emerged the so-called Indigenous paradigm (for a detailed discussion see Chapter 3 in this volume), which can be understood in the context of earlier scientific traditions and their "Western" categories and concepts being taken for granted (see also Kuokkanen 2009). The ideas and values in an Indigenous paradigm according to Rauna Kuokkanen (2000, 411) "is a way of both decolonizing Indigenous minds by 're-centring' Indigenous values and cultural practices and placing Indigenous peoples and their issues into dominant, mainstream discourses which until now have relegated Indigenous peoples to marginal positions". The Indigenous paradigm highlights the fact that research can be transformative, drawing from Indigenous ways of knowing. It can be contextual and local, drawing upon reciprocity and the notion of different culturally and scientifically meaningful measures like, for example, in the research literature that mentions giving, receiving and paying back (Kuokkanen 2007b) and standing with (e.g. TallBear 2014; also Öhman 2014).

Yet, Indigenous knowledges have still been considered static and closed (see Green 2008), or only as something specific for specific groups and contexts, and thus not debatable in academia (see Battiste 2008, 2013; Meyer 2008). However, today Indigenous and scientific knowledges are increasingly regarded as complementary: both can be discussed critically and both can offer innovations. Many researchers are Indigenous themselves, for instance 
in the Sámi context, and therefore dichotomous terms, such as scientific and Indigenous knowledge are not even applicable. According to Fikret Berkes (1999/2012), combining traditional knowledge and the findings of "Western" scientific scholarship are bringing important contributions and solutions to among other things various environmental issues.

The concept of the cultural interface is relevant to describe a space for both Indigenous and non-Indigenous persons living in the border zone between different identities. It helps us to understand the presence or availability of numerous subject positions that an individual person and a community lives by and with. This space is multi-layered and multi-dimensional, and shapes how individuals speak of themselves and about others (Nakata 2007, 199). For scholars of Indigenous issues, this implies seeing Indigenous persons - or everyone they encounter or present through research - as active agents in their own present time. Likewise, it implies that collective Indigenous narratives consist of a collection of complex narratives rather than a single narrative (Nakata 2007, 204-211). Indigenous studies thus work within the context of different contents, even if there are similarities in the processes (cf. Briggs 2013).

\section{5 \\ Indigenous Studies in Sámi Contexts}

The Sámi movement in the 1970s changed many things, including educational changes in Sápmi (Sámi homeland). As mentioned earlier, in 1973 the Nordic Sámi Institute, Davviriikkaid Sámi Instituhtta, was established. This era is a cornerstone in the discussion on Indigenous Research methodologies globally. Furthermore, in the 1980s, Sámi organizations and the Sámi movement called for more places for Sámi students in universities. Consequently, the Sámi University (Sámi allaskuvla) was established in 1989 in Guovdageaidnu, as a Sámi teaching and research institute to support Sámi language and teacher education. It originated from a need for establishing tertiary education in Sámi core area surroundings and environment, and with Sámi as the language of instruction. Davviriikkaid Sámi Instituhtta was combined with the University of Applied Sciences in 2005 .

The Sámi University of Applied Sciences (sUAS) has a responsibility for Sámi higher education given in the Sámi language. suAs has developed its syllabi on the basis of Sámi needs and is developing Sámi as an academic language. The main language of teaching, administration and publication is Sámi. According to Jelena Porsanger (2018), Guovssonásti (the Morning Star) is the symbol for the designation of SUAS, connecting the development process to the Sámi value system. Further, the metaphor of building a lávvu (traditional 
Sámi temporary dwelling tent) has shaped the epistemological platform of the institution (Porsanger 2018).

SUAS offers Sámi language studies from basic courses until doctoral studies, including Sámi teacher education programmes, Sámi journalism studies, reindeer herding, social sciences and Sámi craft and design and other Sámi culture-related shorter and longer courses. All of the studies comprise Indigenous knowledge and Sámi contents in their programmes. Most of the students are from the four Sámi countries with a Sámi population, but students from all over the world have participated in the study programmes. They have supplied culturally meaningful education that has fitted the needs of Sámi society. Since 2012, a new building called Diehtosiida (North Sámi for Knowledge village) has been built in Guovdageaidnu. The special architecture reflects Sámi life, philosophies and worldview, such as a fireplace in the restaurant area, the shape of the building imaging an Arctic fox and views of the surrounding village and landscape from all directions of the building. Guovdageaidnu is in the heart of Sámi land, in the middle of Finnmark county, an upland area of almost 100\% Sámi-speaking inhabitants and traditional land. The establishment of Sámi allaskuvla, attaches Indigenous self-determination in tertiary education and research to global Indigenous development as well as Indigenous research in the Sámi context (Simonsen Thingnes 2020). New fresh study programmes in teacher education have started to produce master's and doctoral theses in Sámi and this research has highlighted Sámi issues.

UiT The Arctic University of Norway, with campuses spread over a large area of northern Norway, was established in 1968. Both Tromsø museum and the teacher education institution, which have become part of UiT, have a longer history of interest in and relevance for Sámi communities. UiT has a particular responsibility for education and research about and for the Sámi communities, and is - alongside SUAS - the most influential and defining institution on the Norwegian side of Sápmi.

Within the Indigenous movement, Sámis have been among the leaders in developing Sámi studies in academia. As a result of the emerging international Indigenist movement, Indigenous research ideas and critical approaches to research practices have expanded, leading to internationally recognized Indigenous research and education alongside more locally and/or regionally based Indigenous studies, such as Sámi studies. Thus, the global dimension of Indigenous studies has meant that insights, experiences, concepts and approaches easily travelled across hemispheres and oceans, and have empowered Sámi studies, among other Indigenous peoples.

UiT was given a special responsibility for research and education on Sámi issues. Today, Sámi and Indigenous issues are a central part of the official 
strategy. There are special programmes and research groups in several parts of the university, such as Sámi health research, Sámi and Indigenous law, and Sámi languages. Since 2003, UiT has also been offering an international Master's degree programme in Indigenous studies. The programme takes its location in the Arctic as a starting point to provide knowledge of the Sámi and other Indigenous peoples of the North. The programme also has a grounding basis in the study of local societies, which reflects the research interests of both teachers and students. A part of the methodological reflection is to challenge and inform students concerning the achievements of different kinds of Indigenous research methodologies.

Indigenous methodologies can be treated as a set of tools that can be used in diverse cultural and historical contexts. On the other hand, Indigenous methodologies can be seen as a locally based theoretical positioning. As such, an Indigenous methodology like Kaupapa Māori is seen as belonging to a specific historical, political and social context. Or perhaps more correctly, what Indigenous methodologies are will vary from one context to another. Following this, the researcher will need to take the particular local community as a starting point for research.

In Finland, studies on Sámi languages and cultures were introduced as early as in the 19th century at the University of Helsinki as part of comparative Finno-Ugric language studies (Riho Grünthal, personal communication). Sámi languages have been taught in addition to Finnish and other languages of the same language family. Since the 1970s, Sámi-speaking university teachers and staff have been employed at the University of Helsinki, and students at Helsinki have been able to specialize in Sámi languages. The Sámi studies programme began at the University of Helsinki in 1993 in order to strengthen the teaching and research in Sámi languages and cultures (Seurujärvi-Kari 2014b). Sámi studies provide education about different Sámi languages and Sámi cultures, while more global Indigenous Studies, which started in 2015, addresses theoretical and methodological issues related to Indigenous knowledge, including Indigenous societies past, present, and future. Its Indigenous Studies programme was founded to develop more ethically sustainable research among Indigenous peoples as well as to theorize Indigenous knowledges that deserve to be critically included in academia. This perspective originates from contacts established with several Indigenous communities. While encouraging Indigenous students to realize that their knowledges and traditional methods do matter and at the same time encouraging students to apply critical approaches, the programme highlights the fact that research and education has a key role to play in inclusivity. This also involves taking into consideration the diversity of Indigenous ideas that academia and global society can benefit 
from. Despite the diversity, there are several common points in Indigenous thinking and values that provide sustainable options.

In Finland, the official national responsibility is to teach Sámi language subject teachers at the University of Oulu, Giellagas Institute. It was also the first university to establish a professorship in Sámi culture in the 1970s. This was followed by founding the Giellagas Institute, the Sámi language and culture institute in the 200os. In the Sápmi area, the University of Lapland in Rovaniemi started to educate Sámi language in the preservice teacher education programme in the late 1970s. It has today two professorships in the Department of Social Sciences, one in Sámi studies and the other in Arctic Indigenous Studies, and in addition, a Sámi language and a culture lecturer position in the Department of Education. Other universities in Northern Europe also conduct Sámi contents in various forms.

The teaching and research goals are different in each presented institution, but they also have certain shared features. As researchers and teachers, we locate ourselves and our programmes both in local and global contexts, depending on actors, time, and purpose. In the Indigenous and Sámi studies programmes students who participate in the study programmes come from diverse cultural, ethnic, linguistic and religious backgrounds. Education on Indigenous societies is greatly needed by those students who might make their careers in different sectors of society. One of the underlying rationales for inaugurating Indigenous studies was the thought that it could benefit students' future careers in policy making, the environment, the sustainability sector, education, social work, health care, law, and other areas of culture.

Since the beginning of Indigenous and Sámi Studies, Indigenous and Sámi studies programmes have also provided a context for local knowledge-making as well as providing a link to global Indigenous debates. This also poses some methodological challenges as we will discuss in the next section.

Research Methodologies in Indigenous Research

With the rise of Indigenous Studies as a discipline, the use of research methodologies has become debated and highlighted in a new way, being more connected to discussions of Sámi research contents more locally. This has meant enabling and empowering Indigenous self-determination in which Sámi researchers document the histories of their own people, that is, their own stories. The aim is to test theories and find solutions to the questions of Indigenous peoples when creating a brighter world for Indigenous communities and people after a long period of cultural colonial practices. These practices 
have led to assimilation and a loss of Sámi ways of living, Sámi cultures and Sámi languages. Indigenous Studies discusses the need to link research objectives and methodologies to community needs and contexts. It involves conducting research respectfully; meaningfully integrating knowledge obtained through research into Indigenous ways of knowing and being; using appropriate interview methods; and engendering a sense of trust and accountability (e.g. Weber-Pillwax 1999). These kinds of approaches have also emerged in participant-focused methodologies and designs (Putt 2013).

In the effort of elevating, discussing, and co-researching Indigenous knowledges, connections to the land, values, and languages, specific Indigenous research methodologies couched in Indigenous terms play a key role. Indigenous methodologies thus rely on Indigenous ontologies, epistemologies, and axiologies (principles regarding values) (e.g. Chilisa 2012, see Chapter 2 in this volume).

In Indigenous research methodologies, holistic approaches are at the core, along with dialogue, connections, collaboration, and relationality (Chilisa 2012). This has been seen as a key to take into account the well-being of the community where matters of academic research are concerned. By highlighting values in Indigenous research methodologies, Indigenous scholars in North America have pointed to the so-called "four Rs": relevance, responsibility, respect, and reciprocal relations in research and education (e.g. Kirkness \& Barnhardt 1991; see also Chapters 3, 8, and 9 in this volume).

Taking Indigenous values seriously has especially impacted the development of a strong ethical framework in research (Battiste 2008; Drugge 2016). This has meant that Indigenous peoples themselves become included in a more horizontal view in the research process from the very beginning, rather than just being asked whether research can be carried out on them. In fact, taking ethical accountability seriously has been an important topic in Indigenous research methodological discussions, since the early debates (see e.g. Weber-Pillwax 1999, 38). Following these discussions, Shawn Wilson (2008) has written about these values enabling relational accountability in Indigenous research. Indigenous research methodologies involve critical reflections concerning cultural sensitivity, cultural protocols, and respectful ways of doing research. They aim to be deeply sensitive towards power issues, towards with whom power rests, and what the possibilities of making research transformative are. Considering one's positionality as a researcher includes several questions, such as one's position in the history of science and who benefits from the research (Bull 2002). These reflections on the researcher's situatedness also include an understanding of what are the scientific concepts that one may take for granted in a research. 
Connected to Indigenous research methodologies, scholars tend to emphasize the need to take into account the whole research process, its past, present and future. Indigenous research methodologies encourage one to think critically about the purpose of one's research, while research design can work towards capacity-building and the role of research collaborators. Alexandra Drawson and colleagues (2017) in reviewing several studies using Indigenous research methodologies point out that the essence of Indigenous research methods is that such research is used to decolonize, heal, and rebalance power. The aim is not merely to produce new knowledge, but to assist community healing and spread transformative knowledge.

Other scholars in the field have also stressed that Indigenous research methodologies should have an overt political agenda related to Indigenous self-determination. Duane Champagne (2014), for instance, has called for centring Indigenous nations and their governance at the heart of the research. In fact, Indigenous research methodologies' aims is to reflect upon knowledgemaking practices and integration of new knowledge in an Indigenous community (Weber-Pillwax 1999, 169). For those who are not Indigenous scholars, it is necessary that their work is accountable and relates to local contexts. Indigenous locations differ, but in this effort Indigenous scholars have also become aware of similarities in their methodologies. Indigenous methodologies can also be employed regardless of one's ethnic identity and background. The need is to draw from ideas that scholars in Indigenous Studies have presented and to focus on local Indigenous contexts.

Education scholar and Pākehā (non-Māori) Alison Jones (2012) writes about the challenges related to being a non-Māori doing research on Māori issues. She refers to Māori scholars, stating that Kaupapa Māori is defined by Māori for Māori and that a non-Māori cannot be involved. In order to be able to engage in such research, they would have to have their authority conferred by whānau (the community) or whakapapa (genealogy). This Kaupapa Māori principle of being for Mãori, by Mãori, is primarily a political statement of inclusion. It is easy for Pākehā to interpret this as a way of excluding them from Kaupapa Māori approaches. However, Kaupapa Māori scholars are not primarily addressing Pākehā, but other Māori scholars. Hence, as a non-Indigenous scholar one needs to be able to decentre oneself in order to be truly informed by Kaupapa Māori (Jones 2012; Olsen 2018).

In discussions about Indigenous research agendas and methodologies, there are good reasons for them to be talked about in the plural. There is no single Indigenous research agenda or methodology. There are numerous subject positions available (Andersen 2009, 92). There are several ways of arriving 
somewhere or at a particular standpoint (Johnston \& Pihama 1995, 83). As scholars within Indigenous studies, we should be careful when it comes to setting strict boundaries between the Indigenous and the non-Indigenous. Such a divide - when holding a premise of purity on each side - is highly problematic. There are many issues that contribute to making this relation more complex. One is the unsolved tension between talking of Indigenous as a local term and talking of Indigenous as a global term. One meaning of the word still continues to have an impact on the other. For the insider/outsider debate, this leads among other things to the question of whether or not an Indigenous person from one part of the world can (claim to) be an insider in the understanding of an Indigenous community in another part of the world. For the highly international and collaborative family of scholars in the field, this is an important matter. To what extent can Indigenous knowledge and perspectives from one Indigenous land and area be applied in another?

In recent years, academic discussion on specific Indigenous research methods has included, among other things, storytelling (e.g. Datta 2018; Kovach 20o9; see Chapter 5 in this volume), dadirri (e.g. West et al. 2012), and yarning (e.g. Bessarab \& Ng'andu 2010) among Australian Aboriginals, talanoa in the Pacific (e.g. Fa'avae et al. 2016), and Anishinaabe symbol-based reflections (Lavallée 2009) in North America. So, recently with more knowledge on Indigenous research methodologies and knowledge-production processes, people have started to draw upon them more centrally in their studies.

In the Sámi context, Sámi research methodologies have been actively discussed in addition to Sámi research in general, as discussed in Chapter 2 of this volume. The roots of Sámi research are found, among other things, in the profound work of the first Sámi author Johan Turi with his detailed descriptions and evaluations of the Sámi culture and its situation, and a bit later in the theories of the very first Sámi scholars, Israel Ruong, Nils Jernsletten, Knut Bergsland, Konrad Nilsen and Tor Frette (Öhman 2014).

After the establishment of the Nordic Sámi Institute in the 1970s further Sámi research started to emerge from different institutions. As mentioned, Sámi research emerged as an inter- and cross-disciplinary approach that dealt with diverse topics: Sámi languages and literature, traditional ways of livelihoods, politics, different cultural expressions of Sámi culture, Sámi arts and duodji (e.g. craftwork), architecture, Sámi health research, and different aspects of Sámi societies conducted by many respected scholars who have done pioneering work in developing Sámi methods and Sámi-centred research. Sámi research is understood as interdisciplinary studies connecting different disciplines when describing traditional ways of living and explaining the history and living conditions of the Sámi people and culture. 
Tove Bull (2002) notes that Sámi research is connected to the histories of different kinds of assimilation policies. The ways of working with this dark past have been the key tools of Indigenous research starting points. Furthermore, Sámi researchers have drawn from their own local concepts central in Sámi onto-epistemologies to express continuity and relatedness, such as oktavuohta (relation, unity), gaskavuohta (reciprocal relationships), birget (well-being) (e.g. Kuokkanen 200o, 2009; Porsanger 2007; Porsanger \& Guttorm 2011), and láhi/attáldat (gift) (Kuokkanen 2006). Kuokkanen (2000, 416) has also referred to the Sámi drum and Deatnu (river), pointing out how these concepts express different connected realms, and a borderlessness and holiness. These have become important ideas for methodological designs. Sámi research has also used lávvu as a methodological tool (see Chapter 2 in this volume). It has been used in different contexts, for instance in language education by Pigga Keskitalo et al. (2013, 8o-81), whose work relied on the idea of enclosing all actors in a language immersion process in order to create a basis for the appreciation of the Sámi language. The model comprises learners, teachers and the environment and takes into account culturally meaningful and landbased learning contexts. Along the same lines in this volume, several chapters reflect on community and land-based methods when engaging in Indigenous research.

\section{Responsiveness in Indigenous Research Methodologies}

Overall, Indigenous research methodologies also allow better Indigenous theorizing (see Chapter 6 in this volume; Simpson \& Smith 2016; Virtanen \& Seurujärvi-Kari 2019). Yet, there are some critical points that have to be taken into account when talking about Indigenous research methodologies. All Indigenous peoples have their own histories, language, and future aspirations. Their methods of living and knowing also differ. There is no one Indigenous method that would be universal and applicable for all. Therefore, there are Indigenous research methodologies, as processes, and specific local understandings of what ways of producing knowledge there are. Consequently, a dilemma, possibility, and/or tension within Indigenous studies and its methods are related to the relationship between what is local, specific, or relevant for one community or group of people on the one hand, and if it can be applicable in other contexts. The question then to reflect on is if the Indigenous methods of other Indigenous peoples are relevant in research. Indigenous peoples have very different academic traditions. Furthermore, should Indigenous research methods be labelled "Indigenous"? Several Sámi researchers, for instance, have for 
a long time been part of academia, and sometimes their traditional ways of knowledge production are present in all their academic practices.

On the other hand, while the use of Indigenous research methodologies can be constructive and make Indigenous knowledge more inclusive in academia, there is a great danger that new ideas are brought to the local contexts, and what is 'local' becomes weaker. Possibly the ways of knowing and disseminating knowledge that are valid elsewhere are not appropriate in a Sámi context. We propose that being conscious of these issues is a step forward.

Overall, Indigenous research practices can be defined as relational and holistic, but universal approaches should be shunned. Hence, what Kaupapa Māori is at its core cannot be strictly defined. Discussing the Kaupapa Māori in 2011, L. T. Smith, for example, is somewhat vague: "It was what it was, it is what it is, and it will be what it will be. It is more than, and less than, other comparative terms. It is more than a theory and less than a theory: it is more than a paradigm and less than a paradigm, it is more than a methodology and less than a methodology" (Smith L. T. 2011, 10; see also Porsanger 2011). This openness, alongside of Chris Andersen's and Jean O'Brien's (2017) notion of methodological 'promiscuity', is a good reminder that Indigenous methodologies are not ideologies or programmes written in stone. When attempting to articulate Indigenous methodology or at least methodological reflections from a global Indigenous studies or Sámi perspective, there is clearly a need to be open to diversity and variation in place and time. We can look at and learn from other parts of the Indigenous world, but we should also remember specific localities and practices.

Andersen and O'Brien (2017) have presented methods used in the field of Indigenous Studies and argue for a methodological 'promiscuity' that reflects the dynamic and pragmatic nature of this new field. In fact, it might seem that anyone researching Indigenous issues might argue that they are doing Indigenous studies. However, a precondition of Indigenous studies is that Indigenous voices, concepts, perspectives and interests are the main emphasis or basis (regardless of how difficult this may be to define) (Smith L. T. 1999/2012). What has been a uniting core in Indigenous studies are critical approaches, and especially the notion of Indigenous paradigm research. Indigenous studies draw on Indigenous frameworks in which Indigenous values, needs, the land, and histories are at the core. Indigenous studies involve elaborating Indigenous research methods, taking them seriously, and emphasizing ethical reflection and sensitivity (Nakata 2007). Marie Battiste (2000, 2013) has argued that self-determination and sovereignty should be the starting point in research related to Indigenous people and Indigenous education. For Battiste (2013), to Indigenize is to give space to different kinds of thinking and 
being. With these ideas in mind, Indigenous studies today can focus on education, health, the environment, literature, political documents, religious rituals, fieldwork, and - quite often - combine a diverse range of sources and types of sources (Andersen \& O'Brien 2017, 4). Having said that, Indigenous studies is still in the making in the "Western" academic world, and its place is not so clear even to those inside academia. One reason for this is that there is not enough knowledge about Indigenous and scientific knowledge, their culturally situated conventions, and what the differences between them are (Bohensky \& Maru 2011).

\section{Inclusivity in Research}

Even though we speak strongly for an Indigenous research paradigm, there is no single Indigenous cultural context, and hence we wish to avoid fixed and bounded oppositions in Indigenous and Sámi studies, such as those between 'the colonized' and 'the colonizer', and 'colonizing' and 'decolonizing. There is clearly a need for decolonization, as mentioned earlier and famously claimed by central scholars like L. T. Smith (1999/2012), Nakata et al. (2012) and Battiste (2013), to mention a few. However, we need to be careful that decolonization does not re-create or imply clear-cut boundaries between people. Rather, Indigenous studies should go beyond dichotomous, clearly bounded, and binary thinking (Virtanen \& Seurujärvi 2019). Nakata and colleagues (2012) have also warned about oversimplification when "Western" and Indigenous standpoints are contrasted as bounded categories. They call for a more openended stance in which the colonial legacy is considered a complex phenomenon, and conceptual limits to an understanding of various positions need to be acknowledged.

Indigenous communities even within one Indigenous nation may have different voices, and that community-making in itself is a constant, ongoing process. Furthermore, differences are endemic, not only between older and younger cohorts, but between those living in forest and urban areas - personal life-stories in particular create different knowledges and ideas about the community. However, all these perspectives are valuable in their own right. These are crucial issues when talking about Indigenous Studies today, as well as when searching to bring Indigenous knowledge into academia more widely. Despite the diversity among Indigenous peoples, there are some common features. Indigenous traditional ways of knowing are concerned with relations to other beings and their knowledges, what Graham Hingangaroa Smith (2003) has called relational knowledge. And of course relationality also exists between 
young and old, between women and men, and human and other-than-human beings. Past, present, and future are also constantly present and interconnected. Traditional ways of knowing, moreover, are about larger complexes, especially when making distinctions between bounded disciplines and different fields of study. Even if we have separate study units with their own learning objectives, it is hard to draw a line between Indigenous history, art, or education.

A widespread collaboration between colleagues in Sámi studies has already been in place for decades, as traditional Sámi lands spread beyond the current national borders. In North European countries, collaboration between scholars from different universities has been a feature of Indigenous and Sámi Studies since their inauguration in different universities. Exchanges take place at both the individual and the institutional level. This collaboration allows local voices to be heard internationally. On the other hand, this has sometimes left us with the dilemma of apparent over-diversity that seems to lack a united perspective. But just as Indigenous studies in general is framed by diversity, acknowledging different voices and diverse starting points is vital, and they can become complementary.

When we have collected course evaluation from the students in the UiT, $\mathrm{UH}$, and sUAs, generally, we could see that Indigenous studies has opened their eyes to see the world, history, and power structures in a new way. With their consent, we can say that they were grateful for being provided with an overview of different approaches, research paradigms, and knowledge traditions, and found themselves sensitized to the exclusion or inclusion of different knowledges in academia. Probably the most diverse group of students in the master's programme in Indigenous studies are at UiT, as a large number of them are estimated to be Indigenous and come from almost all over the world. This diversity is at the same time one of the main assets and one of the biggest challenges of the programme. There is a considerable difference in academic culture between a graduate student from a Nepalese university and a student coming from a Canadian university. As is the difference between a student from Ghana and a student from Russia. Students are encouraged to make their diverse identities and backgrounds a talking point in the classroom. Peer learning is an integral part of the teaching methods, so that the classroom contains several layers or levels. Learning about differences and similarities, and what causes them, is an important part of education. This is an important lesson to learn for students who are both part of a system and at the same time are required to question that system.

L. T. Smith's famous statement in Decolonizing Methodologies is salutary: "Research is probably one of the dirtiest words in the Indigenous world's 
vocabulary" (1999/2012). Also for us, acting in a university in Western Europe, is of course being part of a "Western" educational system. At the same time, we claim that it can be an opportunity for a change. A key issue of Indigenous studies is also to work against hardcore dichotomization of any kind. Thus, it is as difficult to talk of a homogeneous "West" as it is to talk of a homogeneous group of Indigenous peoples. Nonetheless, we ask students to think about the interests and ideas of diverse Indigenous peoples. In order to do that properly, students need to acquire considerable knowledge in order to define what the interests and ideas of Indigenous peoples might actually be.

In this chapter, we have first discussed the growth of Indigenous knowledges and perspectives in academia and then their accountable inclusion through Indigenous research methodologies. We have seen that the discussions have drawn from diverse Indigenous contexts, and they have increasingly become debated also in methodological terms. Local Indigenous methods of producing knowledge as well as the views from Indigenous communities can be transformative at different levels in the communities and in academia.

In this chapter, we also reviewed briefly how the Sámi and Indigenous study programmes have progressed and formed, and what the experiences of students are. These, as well as our research activities, such as the two-year Indigenous Research Methods in the Academia project, showed that there were many different views about what Indigenous knowledge constituted and what could be a leading Sámi idea for our work. Voices coming from different researchers, employing different local and global contexts were crucial for our discussion. Even the understanding in our group among Sámi researchers showed that their views were not unified on what the "Sámi way" of doing research or knowledge-production methods was. The key to creating dialogues, bridges, and peacebuilding, as well as taking steps towards sustainable futures, lies in this very diversity, complexity, and multivocality. We also would like to emphasize that different scholars are needed when offering more critical and decolonial education at university levels (see also Nakata et al. 2012). Indigenous engagement and creation of novel relationships serve as a basis for social and academic inclusion. Awareness of the cultural interface that we work within as scholars of Indigenous and Sámi studies, can be an important tool both used as a mirror and a lens. As we dwell and move within a cultural interface, so do the people and communities of our North. 
We have shown that Indigenous studies moves between and within local and global levels. Local relations have been the starting point in decolonial discussions, while new ideas from other Indigenous contexts as well as sciences have been helpful in elevating the understanding and different voices. Indigenous research methods may originate and be useful at society/nation and community level, yet in some contexts broader discussions, generalizations, and comparisons can be made. Sámi scholar Harald Gaski (2013) has identified local, national, and international levels in Indigenous research, and in our view, a recognition of these different levels can also be useful with methodological considerations and debates. Therefore, with this chapter, we want to point to the responsibility in the use of Indigenous research methodologies, and towards the different levels the methodological discussions can take.

\section{Acknowledgements}

We would like to thank the Finnish Cultural Foundation, the anonymous reviewers for their constructive comments, and lastly all those Indigenous societies who are our research collaborators.

\section{References}

Acheraiou, A. (2008). Rethinking postcolonialism: Colonialist discourse in modern literature and the legacy of classical writers. Palgrave Macmillan.

Andersen, C. (2009). Critical Indigenous studies. From difference to density. Cultural Studies Review, 15(2), 80-100.

Andersen, C., \& O'Brien, J. M. (2017). Sources and methods in Indigenous studies. Routledge.

Battiste, M. (2000). Reclaiming Indigenous voice and vision. UBC Press.

Battiste, M. (2008). Research ethics for protecting Indigenous knowledge and heritage: Institutional and researcher responsibilities. In N. K. Denzin, Y. S. Lincoln, \& L. T. Smith (Eds.), Handbook of critical and Indigenous methodologies (pp. 497-510). Sage.

Battiste, M. (2013). Decolonizing education: Nourishing the learning spirit. Purich.

Berkes, F. (2012). Sacred ecology. Routledge.

Bessarab, D., \& Ng'andu, B. (2010). Yarning about yarning as a legitimate method in Indigenous research. International Journal of Critical Indigenous Studies, 3(1), 37-50. Bhabha, H. K. (1994). The location of culture. Routledge.

Bishop, R. (1996). Collaborative research stories: Whakawhanaungatanga. Dunmore Press. 
Bohensky, E. L., \& Maru, Y. (2011). Indigenous knowledge, science, and resilience: What have we learned from a decade of international literature on "integration"? Ecology \& Society, 16(4), 1-19.

Briggs, J. (2013). Indigenous knowledge: A false dawn for development theory and practice? Progress in Development Studies, 13(3), 231-243.

Bull, T. (2002). Kunnskapspolitikk, forskningsetikk og det samiske samfunnet [Knowlege policy, research ethics and the Sámi society]. In Den nasjonale forskningsetiske komité for samfunnsvitenskap og humaniora (NESH) (Ed.), Samisk forskning og forskningsetikk [Sámi research and research ethics] (pp. 6-21). Publiksjon nr. 2. Forskningsetiske komiteer.

Capdeville, S. (2014). Saamenkielisen kirjakulttuurin synty Suomessa [The birth of book culture in Sámi language]. In P. Keskitalo, V.-P. Lehtola, \& M. Paksuniemi (Eds.), Saamelaisten kansanopetuksen ja koulunkäynnin historia Suomessa [Sámi education history in Finland] (pp. 87-103). Migration Institute.

Centre for Sámi Studies. (2020). About Vardduo. Umeå University. https://www.umu.se/ en/vardduo-centre-for-sami-research/about-the-department/

Chakrabarty, D. (2007). Provincializing Europe postcolonial thought and historical difference. Princeton University Press. (Original work published 2000)

Champagne, D. (2015). Centering Indigenous nations within Indigenous methodologies. Wicazo Sa Review, 3o(1), 57-81.

Chilisa, B. (2012). Indigenous research methodologies. Sage.

Datta, R. (2018). Traditional storytelling: An effective Indigenous research methodology and its implications for environmental research. AlterNative: Journal of Indigenous peoples, 14(1), 1-10.

Deloria, V. Jr. (1970a). Custer died for your sins: An Indian Manifesto. Avon books.

Deloria, V. Jr. (197ob). We talk, you listen: New tribes, new turf. Macmillan.

Deloria, V. Jr. (1998, November 29). Do scientists have rights to all findings? The Denver Post.

Dirlik, A. (2006). Asia Pacific studies in an age of global modernity. Inter-Asia Cultural Studies, 6(2), 158-170.

Drawson, A. S., Toombs, E., \& Mushquash, C. J. (2017). Indigenous research methods: A systematic review. International Indigenous Policy Journal, 8(2), 1-25.

Drugge, A.-L. (Ed.). (2016). Ethics in Indigenous research. Past experiences, future challenges. Vaartoe, Centre for Sámi Research.

Fa'avae, D. Alison, J., \& Manuatu, L. (2016). Talanoa'i’A e talanoa - Talking about talanoa. Some dilemmas of a novice researcher. AlterNative: Journal of Indigenous Peoples, $12(2), 13^{8-15}$ o.

Frantz, F. (1965). A dying colonialism. Growe Press.

Frantz, F. (1967). The wretched of the earth. Penguin. (Original work published 1965) 
Gaski, H. (2004). Nils-Aslak Valkeapää: Indigenous voice and multimedia artist. AlterNative: An International Journal of Indigenous Peoples, 4(2), 155-178. doi:10.1177/ 117718010800400211

Gaski, H. (2013). Indigenism and cosmopolitanism. The pan-Sámi view of the Indigenous perspective in Sami culture and research. AlterNative: Journal of Indigenous Peoples, 9(2), 113-124.

Green, L. J. F. (2008). 'Indigenous knowledge' and 'science': Reframing the debate on knowledge diversity. Archaeologies. Journal of the World Archaeological Congress, 4(1), 144-163.

Guttorm, G. (2011). Árbediehtu (Sámi traditional knowledge) - As a concept and in practice. In J. Porsanger \& G. Guttorm (Eds.), Working with traditional knowledge: Communities, institutions, information systems, law and ethics. writings from the Árbediehtu Pilot project on documentation and protection of Sámi traditional knowledge (pp. 59-76). Dieđut 1/2011. Sámi allaskuvla/Sámi University College.

Helander-Renvall, E. (2016). Sámi society matters (J. Valkonen \& S. Valkonen, Eds.). LUP. Hill, G. (2010). 500 years of Indigenous resistance. PM Press.

Hirvonen, V. (2004). Utsjoen kirkkotuvat. Markkinapaikasta museoksi [Utsjoki church cabins. From a marketplace to a museum]. Utsjokisuun kyläyhdistys ry:n julkaisuja 1. Utsjokisuun kyläyhdistys ry.

Hirvonen, V. (2008). Voices from Sápmi. Sámi women's path to authorship. DAT.

Hutchings, J., \& Lee-Morgan, J. (Eds.). (2016). Decolonisation in Aotearoa: Education research and practice. NZCER Press.

Isaksson, P. (2001). Kumma kuvajainen. Rasismi rotututkimuksessa, rotuteorioiden saamelaiset [Strange portrayal. Racism in race research, Sámi of race theories]. KustannusPuntsi.

Johnston, P., \& Pihama, L. (1995). What counts as difference and what differences count: Gender, race and the politics of difference. In K. Irwin \& I. Ramsden (Eds.), Toi wāhine: The worlds of Māori women (pp. 75-86). Penguin.

Jones, A. (2012). Dangerous liaisons: Pakeha, kaupapa Maori, and educational research. New Zealand Journal of Educational Studies, 47(2), 10-112.

Keskitalo, A. I. (1976). Research as an inter-ethnic relation. Dieđut 7/1994. Arctic Centre, University of Lapland. (Original work published 1974)

Keskitalo, P., Määttä, K., \& Uusiautti, S. (2013). Sámi education. Peter Lang.

Kirkness, V. J., \& Barnhardt, R. (1991). First nations and higher education: The four R's respect, relevance, reciprocity, responsibility.Journal of American Indian Education, $30(3), 1-15$.

Kovach, M. (2009). Indigenous methodologies: Characteristics, conversations, and contexts. University of Toronto Press.

Kuokkanen, R. (2000). Towards an "Indigenous paradigm" from a Sámi perspective. Canadian Journal of Native Studies, $X X(2), 411-436$. 
Kuokkanen, R. (2006). Láhi and Attáldat: The philosophy of the gift and Sámi education. The Australian Journal of Indigenous Education, 34, 20-32.

Kuokkanen, R. (2007a). Reshaping the university: Responsibility, Indigenous epistemes, and the logic of the gift. UBC Press.

Kuokkanen, R. (2007b). The gift logic of Indigenous philosophies in the academy. In G. Vaughan (Ed.), Women and the gift economy. A radically different worldview is possible (pp. 711-783). Inanna.

Kuokkanen, R. (2009). Boaris dego eana: Eamiálbmogiid diehtu, filosofiijatja dutkan [As old as the earth: Indigenous knowledge, philosophies and research]. ČálliidLágádus.

Lavallée, L. F. (2009). Practical application of an Indigenous research framework and two qualitative Indigenous research methods: Sharing circles and anishnaabe symbol-based reflection. International Journal of Qualitative Methods, 8(1), 21-40.

Lehtola, V.-P. (2014). Saamen kielen lehtoraatista Giellagas-instituutiksi [From the Sámi language lecturehood to the giellaas Institute|. In P. Keskitalo, V.-P. Lehtola, \& M. Paksuniemi (Eds.), Saamelaisten kansanopetuksen ja koulunkäynnin historia Suomessa [The Sámi education history in Finland] (pp. 315-319). Migration Institute.

Lehtola, V.-P. (2017). Vanishing Lapps, progress in action. Finnish lappology and representations of the Sámi in publicity in the early 2oth century. Arktika I Sever, 27, 83-102.

Lehtola, V.-P., \& Länsman, A.-S. (2012). Saamelaisliikkeen perintö ja institutionalisoitunut saamelaisuus [The heritage of the Sámi movement and institutionalized Sámihood]. In V.-P. Lehtola, U. Piela, \& H. Snellman (Eds.), Saamenmaa. Kulttuuritieteellisiä näkökulmia [The Sámi land. Cultural scientific perspectives] (pp. 13-35). Finnish Literature Society.

Löf, A., \& Stinnerbom, M. (2016). Making collaboration work - Reflections from both sides. In A.-L. Drugge (Ed.), Ethics in Indigenous research: Past experiences, future challenges (pp. 137-155). Vaartoe - Centre for Sámi Research.

Mao, Y., Peng, K. Z., \& Wong, C. S. (2012). Indigenous research on Asia: In search of the emic components of guanxi. Asia Pacific Journal Management, 29, 1143-1168.

Meyer, M. A. (2008). Indigenous and authentic: Hawaiian epistemology and the triangulation of meaning. In N. K. Denzin, Y. S. Lincoln, \& L. T. Smith (Eds.), Handbook of critical and Indigenous methodologies (pp. 217-232). Sage.

Mignolo, W. D. (2011). The darker side of western modernity: Global futures, decolonial options. Duke University Press.

Mihesuah, D. A., \& Wilson, A. C. (Eds.). (2004). Indigenizing the academy. Transforming scholarship and empowering communities. University of Nebraska Press.

Minde, H. (2003). Assimilation of the Sámi: Implementation and consequences. Journal of Indigenous Peoples Rights, 3, 1-33.

Nakata, M. N. (2006). Australian Indigenous studies: A question of discipline. The Australian Journal of Anthropology, 17(3), 265-275. 
Nakata, M. N. (2007). Disciplining the savages: Savaging the disciplines. Aboriginal Studies Press.

Nakata, M. N., Nakata, V., Keech, S., \& Bolt, R. (2012). Decolonial goals and pedagogies for Indigenous studies. Decolonization Indigeneity, Education \& Society, 1(1), 120-140.

Öhman, M.-B. (2014). Kolonisationen, rasismen och intergenerationella trauman: Analys, reflektioner och förslag utifrån ett skriande behov av samiskLEDD forskning och undervisning [Colonization, racism and intergenerational trauma: Analysis, reflections and proposals based on a crying need for Sámi-led research and teaching]. Centrum for genusvetenskap, Uppsala universitet. https://www.diva-portal.org/ smash/get/diva2:1082858/FULLTEXTo2\#page=99

Olsen, T. (2018). Privilege, decentring and the challenge of being (non)Indigenous in the study of Indigenous issues. Australian Journal of Indigenous Education, 47 (2), 206-215.

Pauls, E. P. (2019). Assimilation. In Encyclopcedia Britannica. https://www.britannica.com/ topic/assimilation-society

Pihama, L. (2016). Positioning ourselves within kaupapa Māori research. In J. Hutchings \& J. Lee-Morgan (Eds.), Decolonisation in Aotearoa: Education research and practice (pp. 101-113). NZCER Press.

Porsanger, J. (2004). An essay about Indigenous methodology. Nordlit: Tidsskrift $i$ litteratur og kultur, 8(1), 105-120.

Porsanger, J. (2007). Bassejoga čáhci: gáldut nuortasámiid oskkoldaga birra álgoálbmotmetodologiijaid olis [The water of the sacred river: The sources of the Indigenous religion of the eastern Sámi examined within the framework of Indigenous methodologies]. Davvi Girji.

Porsanger, J. (2011). The problematisation of the dichotomy of modernity and tradition in Indigenous and Sami contexts. In J. Porsanger \& G. Guttorm (Eds.), Working with traditional knowledge: Communities, institutions, information systems, law and ethics. Writings from the Árbediehtu Pilot Project on documentation and protection of Sami traditional knowledge (pp. 225-252). Dieđut 1/2011. Sámi allaskuvla/Sámi University College.

Porsanger, J. (2018). Building Sámi language higher education: The case of Sámi University of applied sciences. In E. McKinley \& L. Smith (Eds.), Handbook of Indigenous education. Springer. https://doi.org/10.1007/978-981-10-1839-8_40-1

Porsanger, J., \& Guttorm, G. (Eds.). (2011). Working with traditional knowledge: Communities, institutions, information systems, law and ethics. Writings from the Árbediehtu Pilot project on documentation and protection of Sami traditional knowledge. Dieđut 1/2011. Sámi allaskuvla/Sámi University College.

Pulkkinen, R. (2005). Research history of the lappology. In U.-M. Kulonen, I. SeurujärviKari, \& R. Pulkkinen (Eds.), The Saami - A cultural encyclopaedia (p. 506). Finnish Literature Society. 
Putt, J. (2013). Conducting research with Indigenous people and communities. A series of research briefs designed to bring research findings to policy makers. Australian Government. Indigenous Justice Clearinghouse. https://www.Indigenousjustice.gov.au/ wp-content/uploads/mp/files/publications/files/briefo15.v1.pdf

Rantala, L. (2014). Saamen kielen opetus Lapin yliopistossa lukuvuosina 1983-2010 [The Sámi language teaching in the University of Lapland in the academic years 1983-2010]. In P. Keskitalo, V.-P. Lehtola, \& M. Paksuniemi (Eds.), Saamelaisten kansanopetuksen ja koulunkäynnin historia Suomessa [Sámi education history in Finland] (pp. 313-314). Migration Institute.

Rasmus, M. (2014). Pakko lähteä, pakko pärjätä [Forced to leave, forced to cope]. In P. Keskitalo, V.-P. Lehtola, \& M. Paksuniemi (Eds.), Saamelaisten kansanopetuksen ja koulunkäynnin historia Suomessa [Sámi education history in Finland] (pp. 251-262). Migration Institute.

Renan, J.-E. (1871). La réforme intellectuelle et morale [Intellectual and moral reform]. Michel-Lévy frères.

Saïd, E. (2000). Nationalism, human rights, and interpretation. Reflections on exile, and other essays. Harvard University Press.

Saïd, E. (1979). Orientalism. Vintage Books.

Sergejeva [Porsanger], J. (2002). Sámedutkan ja Sámi kultuvrralaš renesánsa: ideála, myhta vai duohtavuohta? Sámi dieđalaš áigečála, 1, 137-143.

Seurujärvi-Kari, I. (2000). Beaivvi mánát: saamelaisten juuret ja nykyaika [The children of the sun: The Sámi people's roots and present life]. Tietolipas. Finnish Literature Society.

Seurujärvi-Kari, I. (2014a). Saami studies. Encyclopedia of Sámi culture. University of Helsinki. https://saamelaisensyklopedia.fi/wiki/Saamentutkimus?setlang=en

Seurujärvi-Kari, I. (2014b). Saamentutkimus, saamen kielen ja kulttuurin opetus Helsingin yliopistossa [Sámi research, Sámi language and culture education in the University of Helsinki]. In P. Keskitalo, V.-P. Lehtola, \& M. Paksuniemi (Eds.), Saamelaisten kansanopetuksen ja koulunkäynnin historia Suomessa [Sámi education history in Finland] (pp. 308-312). Migration Institute.

Seurujärvi-Kari. I., Halinen, R., \& Pulkkinen, R. (2011). Saamentutkimus tänään [Sámi studies today]. Finnish Literature Society.

Simonsen Thingnes, J. (2O20). Making linguistic choices at a Sámi University: Negotiating visions and demands. Current Issues in Language Planning, 21(2), 153-174.

Simpson, A., \& Smith, A. (2014). Theorizing native studies. Duke University Press.

Siva Kumar, R. (1999). Modern Indian art: A brief overview. ArtJournal, 58(3), 14-21.

Smith, G. H. (1997). The development of Kaupapa Maori: Theory and praxis (PhD dissertation). University of Auckland.

Smith, G. H. (2003). Kaupapa Maori theory: Theorizing Indigenous transformation of education \& schooling. The University of Auckland \& Te Whare Wananga o Awanuiarangi: Tribal-university. 
Smith, L. T. (2011). Storying the development of Kaupapa Maori. In J. Hutchings, H. Potter, \& K. Taupo (Eds.), Kei Tua o Te Pae hu proceedings: The challenges of Kaupapa Ma-ori research in the 21st century (pp.10-15). New Zealand Council for Educational Research.

Smith, L. T. (2012). Decolonizing methodologies: Research and Indigenous peoples. Zed Books/Otago University Press. (Original work published 1999)

Spivak, G. C. (1993). Can the subaltern speak? In P. Williams \& L. Chrisman (Eds.), Colonial discourse and postcolonial theory (pp. 66-111). Columbia University Press. (Original work published 1990)

Stordahl, V. (2008). Nation building through knowledge building: The discourse of Sámi higher education and research in Norway. In H. Minde (Ed.), Indigenous peoples: Self-determination, knowledge, indigeneity (pp. 249-266). Eburon.

TallBear, K. (2013). Standing with and speaking as faith: A feminist-Indigenous approach to inquiry. Journal of Research Practice, 10(2). http://jrp.icaap.org/index.php/ jrp/article/view/405/371

Thuen, T. (1995). Quest for equity: Norway and the Sámi challenge. Institute of Social and Economic Research.

Valkonen, J., \& Valkonen, S. (2019). On local knowledge. In T. Eriksen Hylland, S. Valkonen, \& J. Valkonen (Eds.), Knowing from the Indigenous North. Sámi approaches to history, politics and belonging (pp. 12-26). Routledge.

Virtanen, P. K., \& Seurujärvi-Kari, I. (2019). Introduction: Theorizing Indigenous knowledge. Dutkansearvvi dieđalaš áigečála, 3(1), 1-19.

Weber-Pillwax, C. (1999). Indigenous research methodology: Exploratory discussion of an elusive subject. The Journal of Educational Thought, 33(1), 31-45.

West, R., Stewart, L., Foster, K., \& Usher, K. (2012). Through a critical lens: Indigenist research and the Dadirri method. Qualitative Health Research, 22(11), 1582-1590.

Wilson, S. (2001). What is Indigenous research methodology? Canadian Journal of Native Education, 25(2), 175-179.

Wilson, S. (2008). Research is ceremony: Indigenous research methods. Fernwood.

Wilson, S. (2013). Using Indigenist research to shape our future. In M. Grey, J. Coates, M. Yellow Bird, \& T. Heatherington (Eds.), Decolonizing social work (pp. 311-322). Ashgate. 